76 巻 770 号 $(2010-10)$

\title{
リモートセンシングのためのモアレ縞を用いた加速度可視化マーカ*
}

\author{
高木 健*1, 大 政 洋 平*2, 石井 抱*1
}

\section{Acceleration Visualization Marker Using Moiré Fringe for Remote Sensing}

Takeshi TAKAKI*3, Youhei OMASA and Idaku ISHII ${ }^{* 3}$ Department of Artificial Complex Systems Engineering, Graduate School of Engineering, Hiroshima University,
1-4-1 Kagamiyama, Higashi-Hiroshima-shi, Hiroshima, 739-8527 Japan

\begin{abstract}
This paper presents an acceleration visualization marker which can display moire fringe that correspond to a magnitude of acceleration without the use of electronic elements, such as amplifiers, strain gauges and wires. To obtain moire fringe, the marker consists of two plate printed with a line gratings. Numerical value of the acceleration can be obtained from an image of this marker. We propose an image processing method and have experimentally verified the utility of the proposed marker by taking images with a high-speed camera.
\end{abstract}

Key Words : Moiré Fringe, Acceleration, Visualization, High Speed Camera

\section{は じめ に}

計測技術の進歩は，多くの分野に発展をもたらして きた．使用する環境に応じて高性能なものから，小型 軽量, 安価なものまでさまざま開発されている. 近年 用いられている物理量を計測するためのセンサには, 多くの場合, 電気的な要素が用いられている. また, これらのうち計測点に取り付ける必要があるセンサを 用いた場合, センサのある計測点に電力を供給する必 要があり, 配線を用い外部から電力を供給するか, 電 源を内蔵しなければならない，また，センサにて計測 した情報を伝達するための配線または無線機も必要と なる。

このような配線等は環境によっては計測できる対象 を制限する要因になっている.この問題を解決するた めに, 従来より光学要素や超音波などを用いることに より, 計測点に電力を供給する必要がない計測技術も 開発されている．著者らもこれまでに，計測点に電力 を供給する必要がない計測技術として，モアレ縞を応 用し力を可視化するメカニズムを提案してきた ${ }^{(1)(2)}$. またその応用として，ロボットグリッパ(1)や内視鏡器 具 ${ }^{(2)}$ に実装した例を示した.

一方, 工場, 建造物, 橋梁などに生じている物理現 象を計測することにより，保守管理を実現しようとす

\footnotetext{
* 原稿受付 2010 年 3 月 11 日.

*1 正員, 広島大学大学院工学研究科複雑システム工学専攻 (画 739-8527 東広島市鏡山 1-4-1).

*2 広島大学大学院工学研究科複雑システム工学専攻.

E-mail : takaki@ robotics.hiroshima-u.ac.jp
}

る研究が行われている( ${ }^{(3)}-(7)$.また，これらにおいて 振動現象に着目している研究は少なくない( ${ }^{(5)-(7) . 乙 し ~}$ かし，これらの対象は非常に大きいためセンサまで配 線を取り回すことは容易ではない，そこで，計測点に 電力を供給する必要がなく, 加速度を可視化し提示で きるモアレ縞を応用したマーカを提案する．これによ り配線することなく離れた所からでもカメラで本マー カを撮影することにより加速度を計測することが可能 となる.

従来より,モアレ縞を応用し変位を計測する研究が 行われている ${ }^{(8)-(11)}$ 。これらの計測方法も計測点に電 力を供給する必要がない利点があるが, モアレ縞を生 じさせるためにレーザーや縞模様を投影できる特殊な 光源を用いている. 一方, 本手法では自然光でも良く, 上記のような特殊な光源を必要としないのでこれらと は異なる。

本手法では，平行格子が印刷された 2 枚のガラス板 を重ね合わせることによりモアレ縞を生じさせている. 同じ方法にて，モアレ縞を生じさせて変位を計測する 方法も提案されている(12)(13). しかし，加速度には着 目しておらず，さらにカメラを用いて離れた所から情 報を取得することは行っていない。

本論文では，加速度に応じたモアレ縞を提示できる 加速度可視化マーカを提案すること，打よび本マーカ を撮影した画像より加速度情報を取得する方法を示す ことを目的とする．1章では加速度をモアレ縞を用い て可視化する原理について述べ，2 章では本マーカを 
(i)

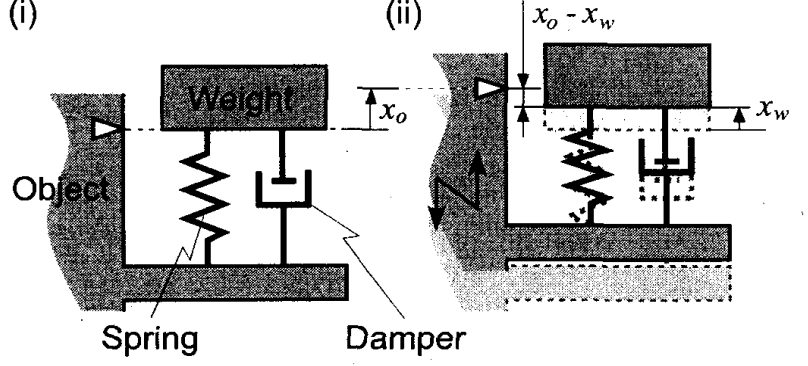

Fig. 1 Seismic system

撮影した画像より加速度情報を取得する方法について 述べる. 3 章では減衰能 ${ }^{(14)}$ に着目し選定した材料を用 いて製作したマーカについて述べ，4 章ではそのマー 力の機械的特性, および高速ビデオカメラを用いて加 速度情報を取得できることを示す． 5 章で考察を述べ， 最後に結論を述べる.

\section{1. 加速度可視化マーカ}

提案するマーカは 1.1 節で述べるサイズモ系よりピッ クアップした加速度を，1.2節で述べるモアレ縞を用 いて視覚的に提示するものであり，その構造について は 1.3 節で述べる.

1.1 サイズモ系と加速度の関係＼cjkstart加速度は図 1(i) のように計測対象と鍾の間をばねとダンパで繋いだサ イズモ系を用いることにより計測できることが知られ ている(12). 計測対象に加速度が生じることにより，図 1(ii) のように計測対象には $x_{o}$ の変位が生じ，錘には $x_{w}$ の変位が生じたとする. また, 計測対象の角振動数 を $\omega_{o}$ とし，錘の固有角振動数を $\Omega_{w}$ とする. $\omega_{o} / \Omega_{w}$ が十分に小さい場合, 計測対象の加速度 $\alpha$ は, 計測 対象と鍾の相対変位 $x_{o}-x_{w}$ に比例し, その比例定数 は鍾の固有振動数 $\Omega_{w}$ の二乗となることが知られてい る.すわわち,

$$
\alpha \simeq \Omega_{w}^{2}\left(x_{o}-x_{w}\right)
$$

となる.これらの関係の導出の詳細については文献 ${ }^{(12)}$ を参考にして頂きたい.

ここで，この式について考える. 固有角振動数 $\Omega_{w}$ は錘の質量とばねのばね定数に依存した定数であるた め, 比例定数 $\left(\Omega_{w}^{2}\right)$ は一定である. 加速度 $\alpha$ に比例 して相対変位 $x_{o}-x_{w}$ が生じるため, 相対変位 $x_{o}-x_{w}$ が可視化できれば，加速度 $\alpha$ を可視化できることにな る. しかし，一般に相対変位 $x_{o}-x_{w}$ は微小あるため, 拡大する技術と組み合わせる必要がある，そこで，次 節で述べるモアレ縞を用いこの相対変位を視覚的に掂 大する.
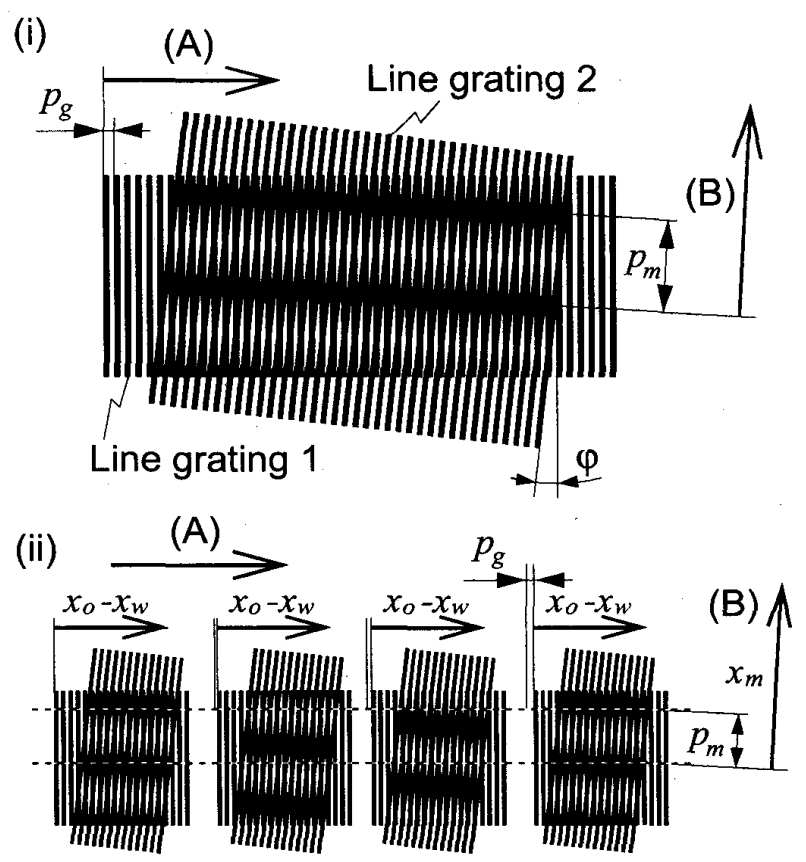

Fig. 2 A moiré Fringe

\section{2 モアレ縞により変位を視覚的に拡大する原理}

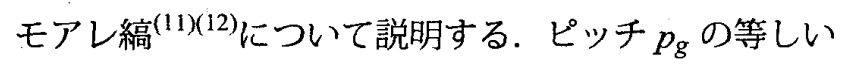
2 枚の平行格子を図 2(i) のように小さな角度 $\varphi$ ほど傾 けて重ねると, 元の格子より間隔の広いピッチ $p_{m}$ の モアレ縞と呼ばれる縞ができる. 図2(ii)のように平 行格子 1 を $(\mathrm{A})$ の方向にピッチ $p_{g}$ だけ変位させると, モアレ縞は (B) の方向にピッチ $p_{m}\left(>p_{g}\right)$ だけ移動 するため, 微小な変位を視覚的に拡大し表示できる. ピッチ $p_{g}, p_{m}$ と角度 $\varphi$ の関係は,

$$
p_{m}=\frac{1}{2 \sin \frac{\varphi}{2}} p_{g}
$$

となるため, $1 / 2 \sin (\varphi / 2)$ 倍に変位を視覚的に拡大す ることができる．これを拡大率 $M$ と定義する.

直線格子の相対変位が $x_{o}-x_{w}$ の場合, モアレ縞の 移動量 $x_{m}$ は次式となる,

$$
x_{m}=M\left(x_{o}-x_{w}\right)
$$

1.3 加速度可視化マーカの構造 1.2 節で述べた モアレ縞にて, 一定の拡大率 $M$ を得るためには, 相対 变位 $x_{o}-x_{w}$ が生じても角度 $\varphi$ を一定に保てる必要が ある. そこで, 図 3(i)に示す 2 枚の同じ形状の薄い弾 性板を持つ平行ばねを用いた，平行ばねは弾性板が 2 枚あるため, 図 3(ii) のように (a) 部に対し (b) 部は角 度 $\varphi$ を変化させることなく相対変位 $x_{0}-x_{w}$ を生じさ せることができる．また, この弾性板の弾性と隇衰能 は，1·1節で述べたサイズモ系におけるばねとダンパ として機能する.これに錘を取り付ければサイズモ系 となり, 相対変位 $x_{o}-x_{w}$ より加速度 $\alpha$ が算出できる. 
(i)

(ii)
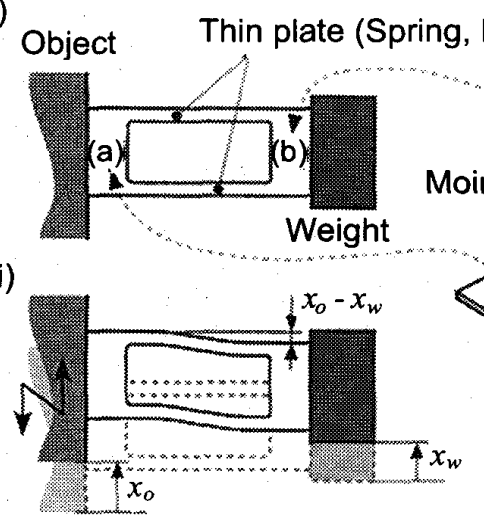

Fig. 3 An acceleration visualization marker

直線格子が描かれている 2 枚のガラス板をそれぞれ (a) 部と (b) 部に取り付ると, 加速度 $\alpha$ に比例する相 対変位 $x_{o}-x_{w}$ をモアレ縞により視覚的に拡大表示で きるため, 視覚的に加速度 $\alpha$ を提示することができる ようになる．以下，これらの部品をまとめて加速度可 視化マーカと呼ぶ。

\section{2. 画像処理による加速度の取得方法}

撮影したモアレ縞の画像の輝度值を $\sin$ 曲線に近似 し,その位相よりモアレ縞の移動量 $x_{m}$ を求め加速度 $\alpha$ を算出する。 これらについて $2 \cdot 1,2.2$ 節で述べる.

\section{1 sin 曲線近似撮影した画像よりモアレ縞を} トリミングし，図 4(i) のように $x, y$ 軸を定義する。 卜 リミングした画像の大きさを $(X, Y)$ とし, $(x, y)$ の位 置にある画素の輝度值を $I(x, y)$ とする.

まず,それぞれの $x$ における $y$ 軸方向の輝度值の平 均 $f(x)$ を求める. $f(x)$ は,

$$
f(x)=\frac{\sum_{k=0}^{Y-1} I(x, k)}{Y}
$$

となる. 次に $f(x)$ を次式の $\sin$ 曲線 $g(x)$ に近似する.

$$
g(x)=A \sin \left(\frac{2 \pi}{p_{i}} x+\theta\right)+B
$$

$f(x)$ と $g(x)$ の例を図 4(ii) に示す. $g(x)$ に近似するた めには，撮影した画像上のモアレ綂のピッチ $p_{i}, モ ア$ レ縞の輝度值の振幅 $A$, 輝度值のオフセット $B, モ ア$ 乙縞の位相 $\theta$ を求める必要がある. $p_{i}$ は $f(x)$ の自己 相関より求まり， $A, B, \theta$ は最小二乗法より求めるこ とができる.

2.2 位相とモアレ縞の移動量 本マーカに加速 度が生じていない静止しているときのモアレ縞の画像 を図 5(i)とする．このモアレ縞の輝度值を式(5)に近似 し，そのときの位相 $\theta$ を $\theta_{0}$ とする（図 5(iii)-(a)）。加 速度が生じ本マ一力に図 3(ii) のように相対変位 $x_{o}-x_{w}$ (i) $I(0,0)$

(ii)

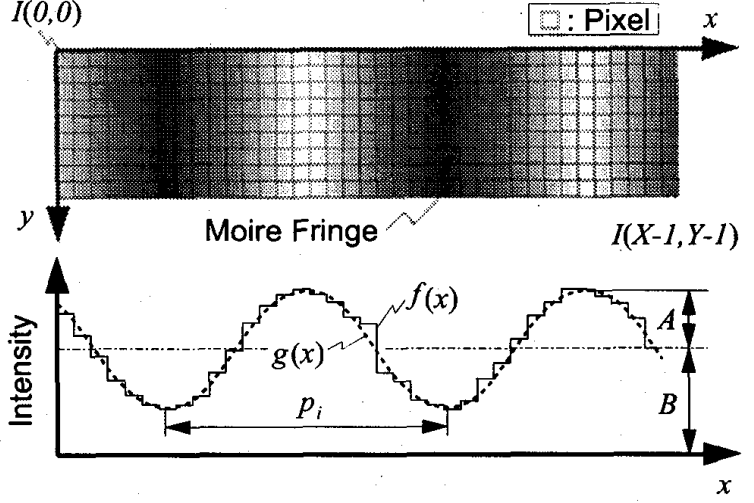

Fig. 4 Intensity of a moire fringe and a fitted curve

が生じると，モアレ縞は式 (3) より $x_{m}$ だけ移動する. 撮影した画像において単位長さが $l$ 画素に相当する場 合，モアレ縞は画像上で図 5(ii) のように $l x_{m}$ だけ移動 する．位相 $\theta$ が図 5(iii)-(b) のように静止時の位相 $\theta_{0}$ に対し $\Delta \theta$ だけ移動した場合，これらの関係は,

$$
l x_{m}=\frac{p_{i}}{2 \pi} \Delta \theta
$$

となる．式 (1), (3), (6) より加速度 $\alpha$ は次式となり 求めることができる.

$$
\alpha \simeq \frac{\Omega_{w}^{2} p_{i}}{2 \pi l M} \Delta \theta
$$

ただし， $\sin$ 曲線 $g(x)$ は周期的な関数であるため, 位 相 $\Delta \theta$ は $\Delta \theta+2 \pi n$ ( $n$ は整数) の值もとり得る. ゆえ に, $n$ についても注意する必要がある. 現在撮影した 画像とその一つ前に撮影した画像から求めた位相 $\Delta \theta$ をそれぞれ $\Delta \theta_{n}$ と $\Delta \theta_{n-1}$ とする. カメラのフレーム レートが十分に早い場合, $\Delta \theta_{n} と \Delta \theta_{n-1}$ の差は小さく なるので,

$$
\left|\Delta \theta_{n}-\Delta \theta_{n-1}\right|<\pi
$$

が成り立つと仮定する，この場合， $\Delta \theta_{n-1}$ が既知であ れば $\Delta \theta_{n}$ の範冊が制限されるため $n$ を定めることがで きる.

\section{3. 製作した加速度可視化マーカ}

製作した加速度可視化マーカを図 6 に示す，弾性板 の材料には M2052 (15)(16) と 2017 を用いた。 M2052 は $\mathrm{Mn} 73, \mathrm{Cu} 20, \mathrm{Ni} 5, \mathrm{Fe} 2$ (原子\%) からなるマンガン ベースの合金であり，極めて大きい減衰能を有してい る. 2017 はアルミニウム合金であり減衰能は小さい. 表面処理には, M2052 は無丽解ニッケル, 2017 は黒ア ルマイトが施されている. 弾性板の形状は同様である.

直線格子のピッチ $p_{g}$ は $0.02 \mathrm{~mm}$ であり, 線の太さ は $0.01 \mathrm{~mm}$ である. M2052 と 2017 の加速度可視化 


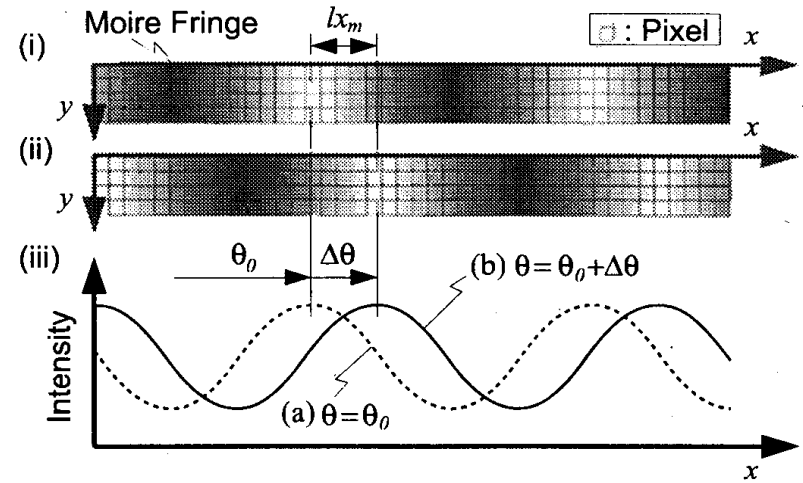

Fig. 5 Phase of a moiré fringe
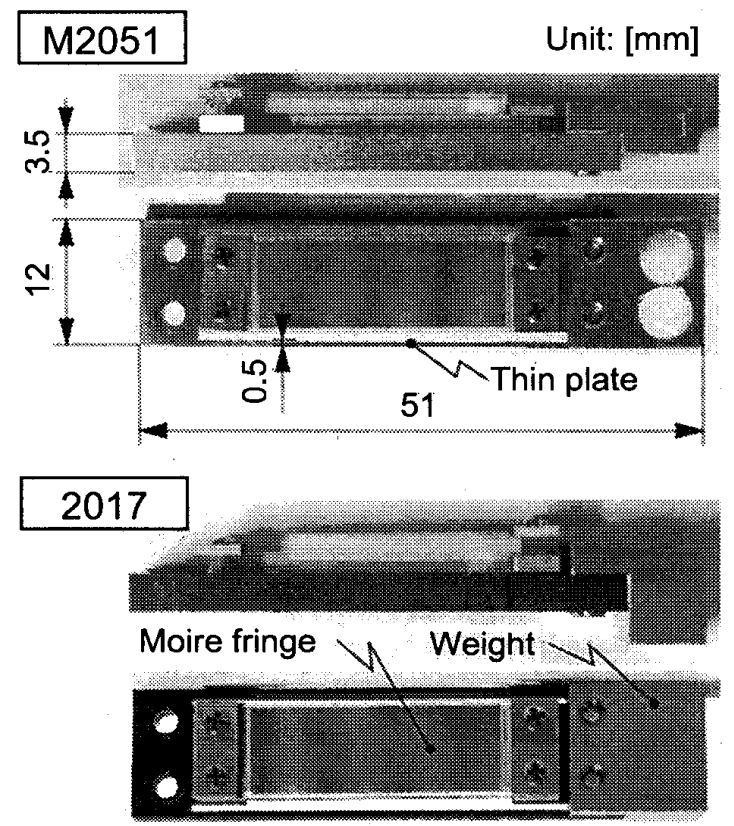

Fig. 6 Developed acceleration visualization marker

マーカのモアレ縞のピッチ $p_{m}$ は，それぞれ $6.1 \mathrm{~mm}$, $5.5 \mathrm{~mm}$ であり, 相対変位 $x_{o}-x_{w}$ をモアレ縞によりそ れぞれ 303 倍, 277 倍に視覚的に拡大して提示するこ とができる.また, マーカの全質量はそれぞれ $11.7 \mathrm{~g}$, $13.0 \mathrm{~g}$ である.

1.1 節にて述べた方法にて加速度を計測する場合, こ れら 2 つのマカを比較するためには固有角振動数 $\Omega_{n}$ は等しいことが望ましい，そこで，錘を少しづつ切削 加工し固有角振動数 $\Omega_{n}$ を調節した. 2 つのマーカで 鍾の形状が異なるのはそのためである、錘の材料には C2801 を用いた. 固角有振動数 $\Omega_{n}$ の詳細については $4 \cdot 1$ 節で述べる.

\section{4. 実験}

$4 \cdot 1$ 節では実験により調べた本マーカの機械的特性 を示す. 4.2 節では実験装置について述べ, 4.3 節にて
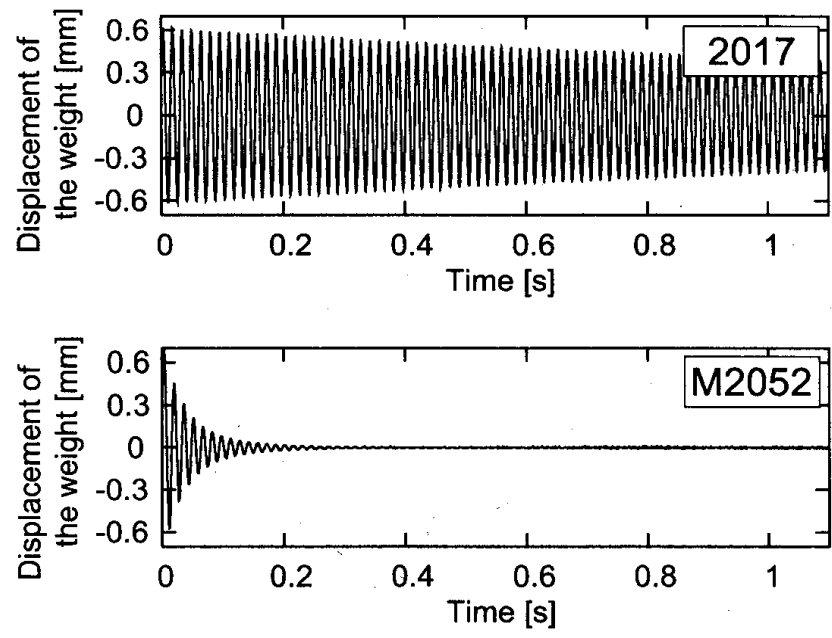

Fig. 7 Damped free vibration

本マーカを撮影した画像より加速度が取得できること を示す。

$4 \cdot 1$ 固有角振動数と減衰比を求める実験 製作し たマーカの力学的特性を調べるために, マーカを自由 振動させ, 鍾の変位をレーザ変位計 (KEYENCE, LKG30）にて計測した．実験結果を図 7 に示す. M2052 と 2017 を用いたマーカの固有角振動数 $\Omega_{n}$ は，それ ぞれ $409 \mathrm{rad} / \mathrm{s}(=65.1 \mathrm{~Hz}), 406 \mathrm{rad} / \mathrm{s}(=64.6 \mathrm{~Hz})$ であり, 減衰比はそれぞれ $0.0473 ， 0.0011$ となった. M2052を 用いた方が 2017 よりも明らかに早く減衰することが 分かる.

4.2 加速度を計測する実験装置 本マーカによ り加速度を計測できるかを検証するための実験装置を 図 8 に示す.M2052 と 2017 を用いたマーカは共に加 振器に固定されている. このマーカを高速ビデオカメ ラにて約 $470 \mathrm{~mm}$ 離れたところから撮影する. 高速ビ デオカメラには，フォトロン社の FASTCAM-1024PCI を用いた. 撮影した画像のフレームレートは $2000 \mathrm{fps}$ で，画像の大きさは $1024 \times 512 \mathrm{pixcl}$ である。このと き, 撮影した画像において $1 \mathrm{~mm}$ は $6.0 \mathrm{pixcl} に$ 相当す る. 比較検証するために, 3 軸加速度センサ (フリー スケール社, MMA7260Q 搭載) も加振器に固定した. LED を用い加速度センサにて計測する值と，本マーカ にて計測する值の同期をとった．また，加振器の振幅を 計測するためにレーザ変位計（KEYENCE，LK-G30） も備え付けられている.

\section{3 加速度可視化マーカを用いた加速度の計測} 2.1，2.2節で述べた画像処理および，4.2節で述べた実 験装置を用い, 製作した加速度可視化マーカより加速 度情報を取得できることを実験により示す。加振器に て本マーカと 3 軸加速度センサを $12.7 \mathrm{~Hz}$ で振動させ 


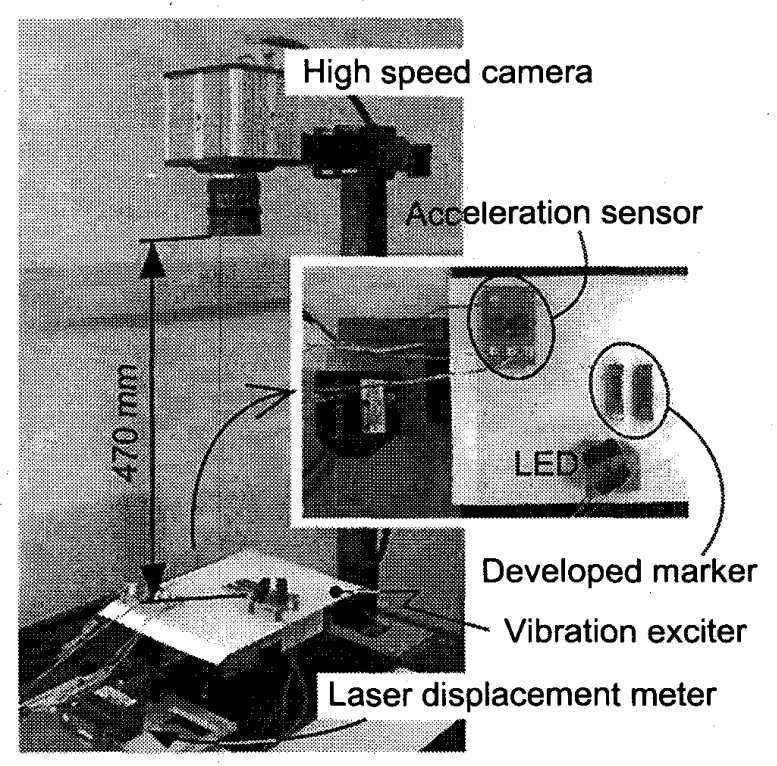

Fig. 8 Experimental setup for developed markers

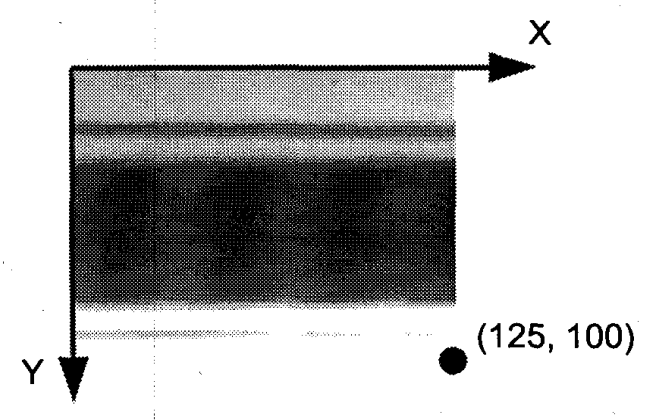

Fig. 9 Image of a moiré fringe

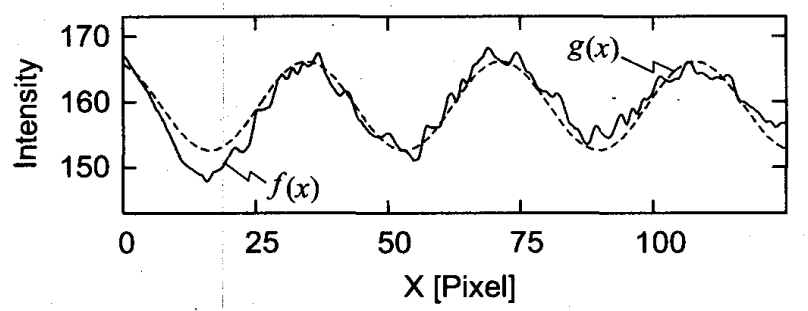

Fig. 10 Intensity of an image and a fitted curve

た.レーザー変位計より計測した加振器の振幅は 0.58 $\mathrm{mm}$ であった. 撮影した画像より, マー力部分をトリミ ングした画像の例を図 9 に示す．画像の大きさは 125 $\times 100 \mathrm{pixcl}$ である. また，この画像の Y 軸方向の輝 度值の平均 $f(x)$ と, $\sin$ 関数に近似した曲線 $g(x)$ を図 10 に示す。

撮影した画像より求めた加速度を図 11 に示す。 上 側は M2052 を用いたマーカより算出した加速度であ り，下側は 2017 を用いたものである．また，比較の ために 3 軸加速度センサにて計測した加速度も共に示 してある.M2052を用いたマーカの計測值は 3 軸加速
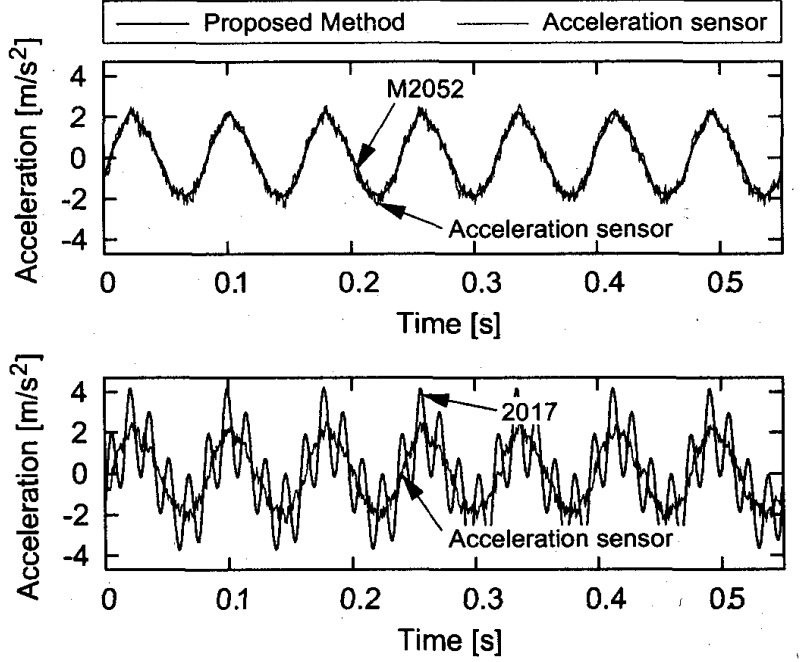

Fig. 11 Experimental result of the acceleration

度センサの計測値と良く一致している. 一方, 2017 を 用いたマーカには, 約 $65 \mathrm{~Hz}$ の振動が加わっている. 3 軸加速度センサにて計測した加速度を真值と仮定して 求めた二乗平均平方根誤差は，M2052，2017を用いた マーカではそれぞれ $0.24,1.4 \mathrm{~m} / \mathrm{s}^{2}$ となった. M2052 を用いたマーカの方が高い精度で計測できていること が分かる.

\section{5. 考察}

4.3 節の実験結果において, 3 軸加速度センサおよ び M2052，2017を用いたマーカにて計測した加振器 の加速度にどのような周波数成分が含まれているかを 調べるために求めたパワースペクトルをそれぞれ上か ら順に図 12 に示す. 全てにおいて $12.7 \mathrm{~Hz}$ 辺りに大 きな值を示しているのは, 加振器の振動によるもので あると考えられる. 2 つのマーカの固有角振動数 $\Omega_{w}$ は共に約 $400 \mathrm{rad} / \mathrm{s}(65 \mathrm{~Hz})$ であるが, M2052 を用いた マーカはこの振動数辺りに大きな值を示していないの に対し，2017を用いたマーカでは大きな值を示して いる.これは 2017 のマーカの減衰比は 4.1 節で述べ たように小さいため, 加振器の振動に含まれるわずか な $65 \mathrm{~Hz}$ の成分にも大きく共振したためであると考え られる.よって, 加速度可視化マーカには，2017より も減衰能が大きい M2052 の材料の方が適しているこ とが分かる.

\section{おわりに}

モアレ縞を用いて加速度を可視化し提示するマーカ を提案した. 本マーカを高速ビデオカメラにて撮影し 画像を処理することにより, 画像より加速度情報を得 られることを示した。 また，材料の減衰能に着目し， 

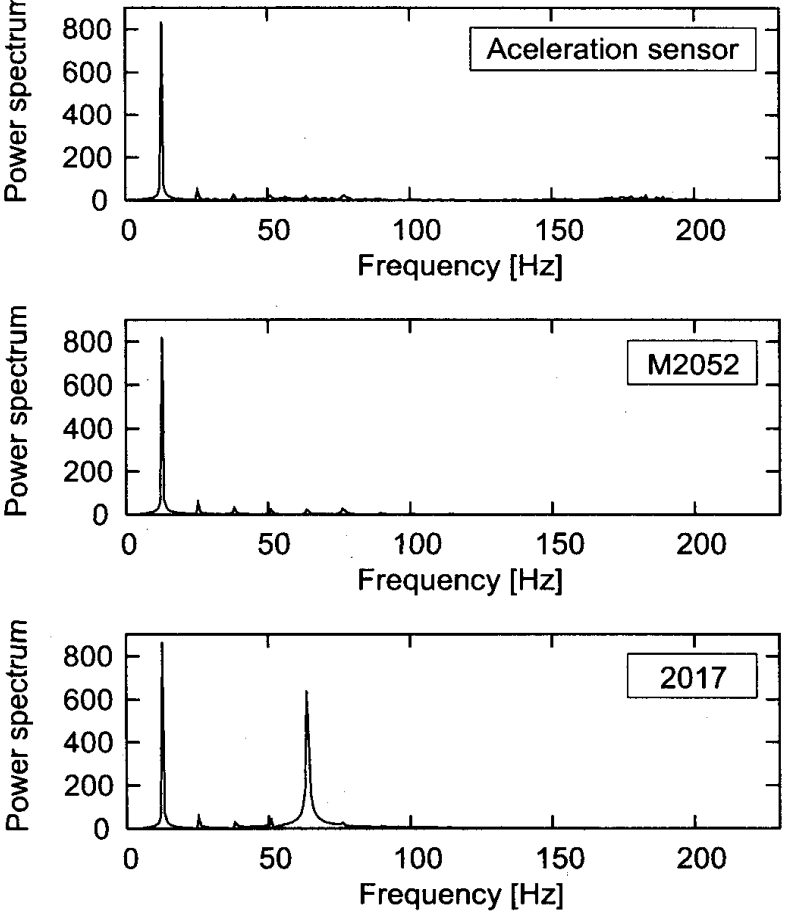

Fig. 12 Experimental result of the power spectrum

減衰能がマーカの精度に大きく影響することを実験よ り示した. 今後, 本マ一力を建造物に取り付け望遠レ ンズを用いることにより, 数十メーター離れたところ から加速度を計測する予定である。

\section{文献}

(1) Takaki, T., Omasa, Y. and Ishii, I., Force Visualization Mechanism using Moire Fringe for Robot Grippers, The 28th Annual Conference of the Robotics Society of Japan, 1K3-07, 2008.

(2) Takaki, T., Omasa, Y., Ishii, I., Kawahara, T., Sumitani D., Yoshida, M. and Okajima, M., Force Visualization Mechanism using Moire Fringe for Endoscopic surgical Instruments, Journal of Japan Society of Computer Aided Surgery, Vol. 114, No. 4, pp. 447-456, 2009.

(3) Fukuda, T., Osaka, K., Mashima, M., and Miki, M., Flexural Behavior of Concrete Beam Reinforced by GFRP Rod and Health Monitoring Using Optical Fiber, Journal of the Society of Materials Science, Japan, Vol. 42, No. 475, pp. 442-448, 1993.

(4) Takeda, N. and Okabe, Y., Health Monitoring of Composite Materials Using Optical Fiber Sensors, Transactions of the Japan Society of Mechanical Engineers, Series A, Vol. 67, No. 655, pp. 378-383, 2001.

(5) Tamura, M., Yamamoto, S., Sono, A., and Masuda, A., Measurement of Dynamic Strain of Structure Subjected to Dynamic Load by Using a Couple of Vibratory Gyroscope, Journal of Structural and Construction Engineering (Transactions of Architectural Institute of Japan), No. 509, pp. 61-68, 1998.

(6) Jiang, Z. and Takeuchi, Y., Health Monitoring Technique for Truss Structure with PZT Patches, Transactions of the
Japan Society of Mechanical Engineers, Series C, Vol. 69 , No. 679, pp. 586-593, 2001.

(7) Hamamoto, T., Ohmura, T., Horiuchi, D., and Choi, J., Laboratory Experiments on Integrated Health Monitoring of Cast-in-Situ Concrete Pile Foundations Using Vibration and Wave Measurements, Journal of Structural and Construction Engineering (Transactions of Architectural Institute of Japan), No. 616, pp. 105-112, 2007.

(8) Suzuki, S., Morita, Y. and Sakaue, K., Measurement of Opening Displacement of Bifurcated Cracks by HighSpeed Holographic Microscopy and Moiré Interferometry, Transactions of the Japan Society of Mechanical Engineers, Series A, Vol. 67. No. 655, pp. 432-439, 2001.

(9) Arakawa, K., Ishiguma, M. and Takahashi, K., Measurement of Crack Opening Displacement in Mode I Interlaminar Fracture of CFRP by Moire Interferometry, Transactions of the. Japan Society of Mechanical Engineers, Series A, Vol. 59. No. 559, pp. 553-557, 1993.

(10) Ma, y., Kurita, M. and Sasaki, A., Effect of Out-of-Plane Rotation on Strain and Displacement Measurement by Moiré Interferometry, Transactions of the Japan Society of Mechanical Engineers, Series A, Vol. 59. No. 567, pp. 2605-2611, 1993.

(11) Yamada, T. and Yokozeki, S., Measurement Methods Using Moire Techniques and/or Interferometry, Corona Publishing Co., Ltd., pp. 48-220, 1996.

(12) Taniguchi, O. and Horigome, Y., Measurement Engineering, Second Edition (in Japanese), Morikita Publishing Co., Ltd., pp. 103-104, pp. 194-198, 1991.

(13) Masanao, M., Sensing Techniques of Mechanical Quantities, Corona Publishing Co.; Ltd., pp. 114-117, 1986.

(14) Metal editorial department, Dictionary to know metal (in Japanese), Agne Co., Ltd., pp. 46-51, 1978.

(15) Kawahara, K, Sakuma, N and Nishizaki, Y., Effect of Third Elements on Damping Capacity of Mn-20Cu Alloy, Journal of the Japan Institute of metals, Vol. 57, No. 9, pp. 1089-1096, 1993.

(16) Kawahara, K, Sakuma, N and Nishizaki, Y., Effect of Fourth Elements on Damping Capacity of $\mathrm{Mn}-20 \mathrm{Cu}-5 \mathrm{Ni}$ Alloy, Journal of the Japan Institute of metals, Vol. 57, No. 9, pp. 1097-1100, 1993. 